\title{
Osmanlı Kayıt Kültüründe Vakıf Muhasebesi ve \\ Devlet Muhasebe Sistemi
}

Öz

Oktay Güvemli*

Batuhan Güvemli**

Osmanlı İmparatorluğu’nda vakıfların iki önemli dayanağı vardır. Bunlardan ilki hukuk düzenidir. İkincisi de muhasebe kontrolüdür. Muhasebe kontrolü, vakfin bulunduğu yerde tutulan muhasebenin yıllık gelir ve gider kayıtlarının, kadı kontrolünden geçtikten sonra merkez muhasebesine gelmesi ve orada gelir gider defterinin yeniden düzenlenmesi şeklinde olmaktadır. Devlet muhasebesinde kullanılan merdiven yönteminin vakıf muhasebesinde kullanılması bir istisna teşkil eder.

Merkezî vakıf muhasebesinin içinde bulunduğu Osmanlı'nın merkezî devlet muhasebesi büyük bir örgüttür ve bu örgüt, devlet muhasebesinde yıllık kesin gelir ve gider hesabını düzenlemek, devlet hazinesini yönetmek ve sürekli denetleme yapmak sureti ile görevini sürdürür.

Anahtar Kelimeler: Osmanlı İmparatorluğu, devlet muhasebesi, vakıf muhasebesi.

Jel kodu: M41, M19

\section{Waqfs and State Accounting Systems in the Ottoman Administration}

\begin{abstract}
Waqfs in the Ottoman Empire are established on two baselines. The first one is the legal order and the second is the governance of accountancy. Accounting is controlled by sending the annual revenue and expenditure records of the waqfs to central accountancy after audited by the kadı. Afterwards, revenue and expenditure journals are rearranged according to the outcome of the auditing activities. The usage of the state accounting method titled merdivan in waqf accountancy is an exceptional situation. Central accountancy organization of the Ottoman Empire is a great structure that embodies central waqf accountancy. This central accountancy records the exact annual revenues and expenditures of the state, administrates state treasury, and continuously performs auditing activities.
\end{abstract}

Keywords: Ottoman Empire, state accountancy, accounting of waqfs.

Jel Classification: M41, M19

* Prof. Dr., Marmara Üniversitesi Emekli Öğretim Üyesi

** Doç. Dr., Trakya Üniversitesi İktisadi İdari Bilimler Fakültesi Öğretim Üyesi; bguvemli@yahoo.com

Vakıflar Dergisi 46- Aralık 2016

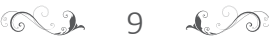




\section{Giriş}

C smanlı Imparatorluğu'nda vakıflar ve devlet muhasebesinin müşterek tarafi her ikisinde de merdiven yöntemi denilen devlet muhasebe yönteminin kullanılıyor olmasıdır. Merdiven yöntemi, Abbasilerde (7701258) doğan, IIlhanlılarda (1256-1353) gelişen ve Osmanlılarda (1299-1922) mükemmelleşen bir yöntemdir. IIlhanlılar döneminde bu yöntemi tanıtan dört kitap yazılmıştir. Bunların en ünlüsü 1363 yılında yazılmış olan Risale-i Felekiyye'dir (Güvemli ve Toraman, 2013: 15). Ana tutarın başa yazılması ve onu oluşturan tutarların alt alta merdiven basamağı gibi sıralanması bu adı almasına neden olmuştur. Farsçası merdibân-ı pâye'dir. Devlet muhasebesinde siyakat harf ve rakamları kullanılır. Siyakat, Osmanlı'da devlet muhasebesinde ve dış yazışmalarda kullanılan bir yazı türüdür. Merdiven yöntemi, yukarda da belirtildiği gibi, Osmanlı'da iki yerde kullanılmıştr. Bunlardan birisi devlet muhasebesi, öteki de vakıf muhasebesidir.

Merdiven yöntemi, 1879 yılında yerini bugün yararlanılan çift yanlı kayıt yöntemine bırakarak tarihteki görkemli yerini almıştır. Buna göre yöntem 770-1879 yılları arasında yaklaşık 1100 yıl boyunca bu topraklarda kullanılmıştir. Abbasilerde uygulanması ile ilgili Alman kaynaklarında örnekleri bulunmaktadır (Güvemli ve Güvemli, 2007:9).

Arşivlerde, hem devlet muhasebesinde ve hem de vakıflarda merdiven yöntemi ile tutulan ve bugünlere kadar gelen binlerce muhasebe defteri vardır.

\section{Vakıf Muhasebesi}

Osmanlı'da vakıfların uzun ömürlü olmalarının iki nedeni vardır. Birisi sağlam bir hukukî yapıya sahip olmaları, ikincisi de sürekli muhasebe denetimi içinde olmalarıdır. Muhasebe düzenleri öyle kurulmuştur ki, bu düzen onların sürekli muhasebe denetimi altında tutulmalarını mümkün kılmıştır. Asırlar boyu, imparatorluğun sosyo-ekonomik yapısında önemli bir rol oynamışlardır. Ömer Lütfü Barkan'ın 1530-1540 yılları arasındaki tahrirlere dayanarak yaptığı hesaplamalarda, Anadolu'da kamu gelirlerinin \%17'sinin; Rumeli'de de, büyük sultan vakıflarının da içinde bulunduğu, İstanbul civarı ile doğu ve batı Trakya, güney Bulgaristan ve Makedonya bölgesinin oluşturduğu alanda \%32 oranındaki kamu gelirlerinin vakıflar tarafindan kontrol edildiği belirtilmektedir (Barkan, 1962: 1-2). Vakıfların bu ekonomik gücünün uzun süre devam ettiği, XIX. yüzyılın ikinci yarısında, bütün dünyada olduğu gibi, Türkiye'de de sosyal gereksemeleri karşılayan vakıf konularının devlet bütçesi içine alınması ile bu gücün kaybolduğu bilinmektedir. Vakıflar yine var olmuşlar, ama ağırlıkı olarak kültürel alanda faaliyetlerini sürdürmüşlerdir (Şensoy, 2016: 43).

Osmanlı'da iktisadî açıdan devletçi bir yapı olduğu için, özel kesimde yaygın bir sermaye birikimi olmamıştr. Özel kesim olsun, devletin yöneticileri olsun vakıflar kanalı ile bir ekonomik güce sahip duruma gelmişlerdir. Sultanların ve devlet yöneticilerinin vakıf kültürüne yakınlık duyup, vakıflar kurmalarının da etkisi ile merkezi devlet muhasebesindeki muhasebeciler vakıfların muhasebe denetimlerine sürekli ilgi göstermişlerdir. Hatta Osmanlı merkez muhasebesinde her zaman vakıflar ile ilgili olarak bir departman bulunmuştur (Güvemli, Toraman ve Güvemli, 2014: 371-400). Yüzer yıl ara ile Osmanlı merkez muhasebesinde bu departmanların adları ve özet olarak görevleri aşağıda ele alınmıştır.

\subsection{Küçük Evkaf Muhasebesi Kalemi: 1560, 1670 ve 1787 Yılları}

Ahmet Akgündüz'ün Osmanlı Kanunnameleri (1992: 594 vs.) adlı eserinde bu kalem, 1560'lı (H. 973) yıllarda bazı vakıfların ve Sadrazamlığa bağIı, yoksullara yardım kurumlarının yöneticilerinin berat belgelerinin düzenlendiği ve bu kuruluşların muhasebelerinin tutulduğu departman olarak anlatılmaktadır. Topkapı Sarayı'nda bulunan 1670 (H.1081) yılına ait 3208/1 numaralı (Bkz. Ek.1) belgede merkezi muhasebe departmanındaki kalemler sıralanmıştr. Bu doküman içerisinde de Küçük Evkaf Muhasebesi Kalemi ile ilgili bilgiler verilmektedir (Bkz. Güvemli, Toraman ve Güvemli, 2014: 375). Kalemin görevleri Akgündüz'ün 1560'ı yıllara dayandırdığı açıklamalar ile benzerlik göstermektedir. Kalem, ayrıca D'ohsson'un 1787 yllına ait Tableau General de L'Empire Otho- 
man adlı eserinde de anlatımakta ancak kalemin görevlerinde herhangi bir değişikten bahsedilmemektedir.

\subsection{Haremeyn Muhasebesi Kalemi: 1560, 1670 ve 1787 Yılları}

Ahmet Akgündüz'ün Osmanlı Kanunnameleri (1992: 594 vs.) adlı eserinde bu kalem, 1560'ı (H. 973) yıllarda Saraya ait gelir yerlerin (mukataa) muhasebesi ile saray mensuplarının vakıflarının muhasebelerinin tutulduğu departman olarak anlatılmaktadır. Topkapı Sarayı'nda bulunan 1670 (H.1081) yılına ait 3208/1 numaralı (Bkz. Ek.1) belgede merkezi muhasebe departmanındaki kalemler sıralanmıştır. Bu doküman içerisinde de Haremeyn Muhasebesi Kalemi ile ilgili bilgiler verilmektedir (Bkz. Güvemli, Toraman ve Güvemli, 2014: 373). Kalemin görevleri Akgündüz'ün 1560'। y yıllara dayandırdığı açıklamalar ile benzerlik göstermektedir. Kalem, ayrıca D'ohsson'un 1787 yllına ait Tableau General de L'Empire Othoman adlı eserinde, İstanbul ve Rumeli'deki camilerin donanım masraflarııın hesaplarının, Mekke ve Medine'ye giden alayların hesaplarının tutulduğu departman olarak anlatımaktadır. 1761'de devlet kesin hesabında bu departmanın gelirlerinden söz edildiğine göre, yine saraya ait vakıfların muhasebesi ile meşgul olması da muhtemeldir.

Yukarıdaki bilgilere göre, Osmanlı'nın merkez muhasebesinde vakıflar ile ilgilenen iki departman vardır. Bunlardan Haremeyn Muhasebesi'nin saray mensuplarının vakıfları ile meşgul olmak üzere, Hürrem Sultan zamanında (1559'ler) kurulduğu ve vakıflar ile ilgilenmeye başladığı bilinmektedir. Saray mensuplarına ait vakıflarda ortaya çıkacak bir usulsüzlüğün skandala yol açması kaçınılmaz olduğu için, başdeftardarın muvafakatı alınarak, saray mensuplarının vakıfları için ayrı bir muhasebeci grubunun görevlendirildiği anlaşılmaktadır.

Bilgilerin akışından, muhasebe ve denetim düzeninin şu şekilde yürütüldüğü ortaya çıkmaktadır: Vakfin bulunduğu yerde muhasebesi vardır, muhasebecisi vardır. Vakıf senedine göre, gelir ve giderler buradaki muhasebeciler tarafindan muhasebe defterlerine kayıt edilmektedir. Vakfin bulunduğu yerin kadısı bu kayıtları kontrol eden ve vakıf senedine uygunluğunu denetleyen ilk kişidir. Birçok vakfin muhasebesindeki kadıya verilen ücret bunu gösteriyor. Saray mensuplarına ait vakıfların defterleri Haremeyn Muhasebesi'ne, öteki vakıfların defterleri Küçük Evkaf Muhasebesi Kalemi'ne geliyor.

Merkez muhasebeye gelen belgeler üzerinde iki işlem yapılmaktadır. Bunlardan ilki, vakıf senedi ve önceki yıl ile karşılaştrılarak vakıf faaliyetlerinin uygunluğunun kontrolüdür. İkinci işlem ise, muhasebe tekniği ile ilgilidir. Merdiven yöntemini taşradaki muhasebeciler gereğince bilemedikleri için, bu muhasebe usulüne (merdiven yöntemi) göre muhasebe defterinin yeniden düzenlenmesidir.

Vakıf muhasebesinde, vakfin bulunduğu yerde tutulan ve merkezde yeniden düzenlenen muhasebe defterleri örneği üzerinde aşağıda durulmuştur (Bkz. Belge 1).

\section{3- Taşra ve merkez muhasebe bilgilerinin kıyaslanması}

Rumeli'deki Güvemli Bey Vakfi'nın H. 1127 - M. 1715 yılının Mart ayında sona eren yıllık gelir ve gideri, vakfin bulunduğu yerde aşağıdaki gibi kayıtlara geçirilmiştir (Bk. Belge 1 ve çevirisi).

Belge 1 ile ilgili aşağıdaki bilgileri vermek gerekmektedir:

Yıllık muhasebe defteri bir muhasebecinin sorumluluğunda düzenlenmiştir.

Kayıtlar merdiven yönteminin gerektirdiği bilgi ile değil muhasebecinin olgunlaşmamış genel muhasebe bilgisine dayalı olarak yapılmıştır. Bu durum, taşra muhasebecisinin merdiven yöntemi (Osmanlı usul-ü muhasebe demektedir) bilgisinin sınırlık olduğunu göstermektedir.

Gelirlerde zamanın para birimi $A$ kçe sözcügü kullanılmamıştr. Sadece tutar denilmiştir. Hububat ağılık ölçüsü olarak key/ kullanılmıştır.

Gider, gelirlerden fazladır, ama farkın nereden ve nasıl karşılandığı açıklanmamıştır. 
Belge 1. Güvemli Bey Vakfínın H. 1127 / M. 1715 yılı muhasebesi. (BOA, Ev HMH d. 02051: 1)
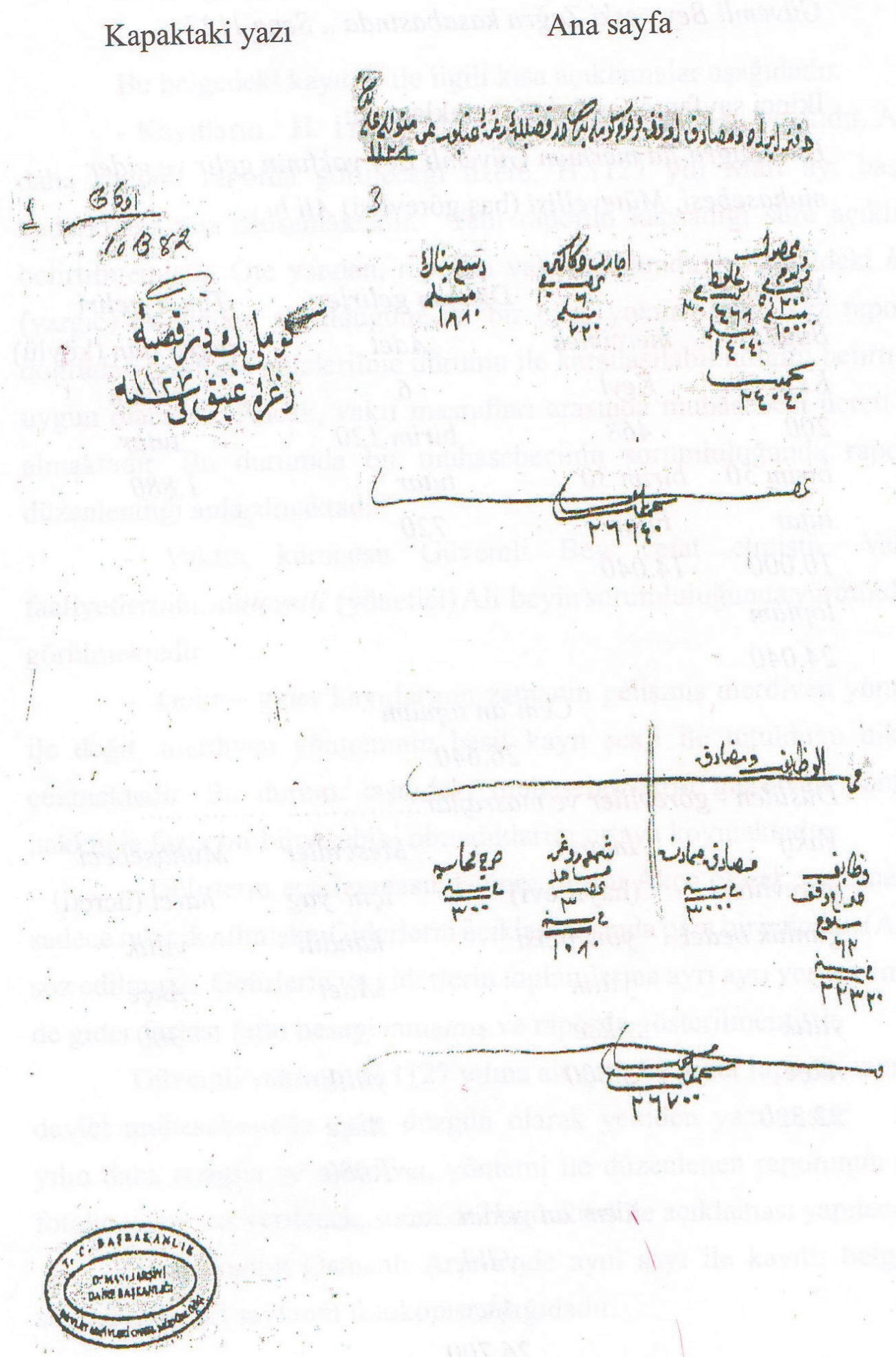
Tablo 1. Güvemli Bey Vakfinın H. 1127 / M. 1715 yılı muhasebesi, kapak ve 1. sayfa çevirisi.

\begin{tabular}{|c|c|c|c|c|}
\hline \multicolumn{5}{|c|}{ Eski Zağra'da merhum Güvemli Bey Vakfinın Gelir ve Gider Muhasebesi. Mütevelli Ali Bey. } \\
\hline \multicolumn{3}{|c|}{ Mahsul } & Dükkan kira gelirleri & Vakfa tahsis olunan vergi geliri \\
\hline Buğday: & & Mercimek & Adet: 6 & \\
\hline Keyl: 200 & & Keyl: 468 & Birim: 10 & \\
\hline Birim: 50 & & Birim: 30 & Tutar: 720 & Tutar: 1.880 \\
\hline Tutar: 10.000 & & Vutar: 14.040 & & \\
\hline \multicolumn{3}{|c|}{ Toplam: 24.040} & & \\
\hline \multicolumn{5}{|c|}{ Genel Toplam: 26.640} \\
\hline \multicolumn{5}{|c|}{ Düşülen Görevli Ücretleri ve Masraflar } \\
\hline \multirow{2}{*}{\multicolumn{2}{|c|}{$\begin{array}{l}\text { Vakıf görevlileri ücreti } \\
\text { Günlük bedel: } 62 \\
\text { Yıllık akçe: } 22.320\end{array}$}} & Imaret Masrafı & $\begin{array}{l}\text { Mescidler için yağ } \\
\text { kandili adet: } 3\end{array}$ & Muhasebeci harcı \\
\hline & & Yıllık: 3.000 akçe & Yıllık: 1.080 akçe & Yıllık: 300 akçe \\
\hline \multicolumn{5}{|c|}{ Genel Toplam: 26.700} \\
\hline
\end{tabular}


Belge 2. Güvemli Bey Vakfinın Merkez muhasebecileri tarafindan tutulan H. 1127 / M. 1715 yılı muhasebesi (BOA, Ev. HMH. d. 02051)

İkinci sayfa
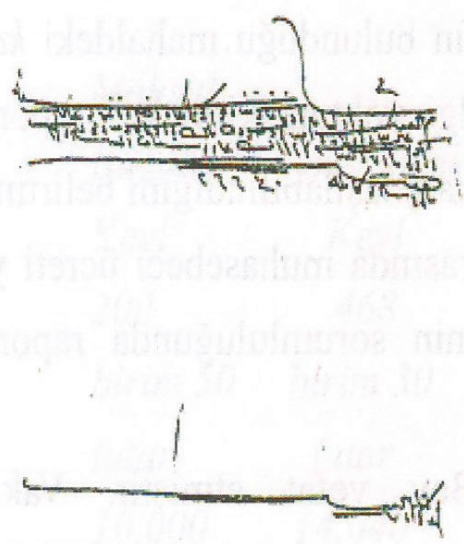

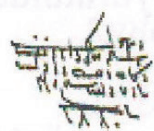
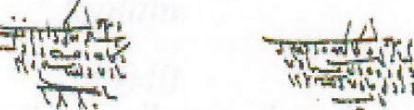

(4)

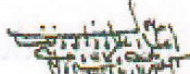

$+1 \mathrm{i}<\mathrm{in}$

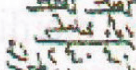

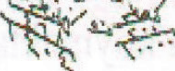
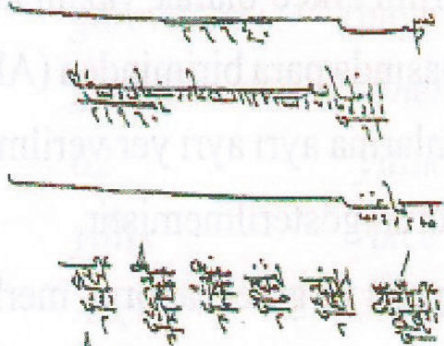

ets

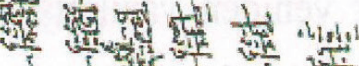
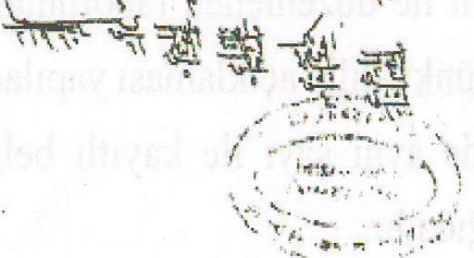

Vakıflar Dergisi 46- Aralık 2016

$$
\text { GC } 14
$$

\section{İlk sayfa}

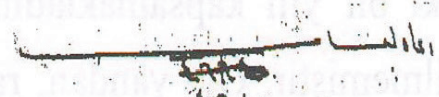

Lid

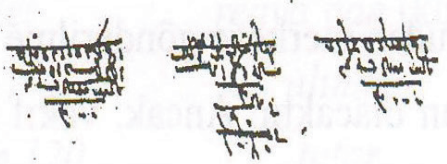

प्रत्यायुग

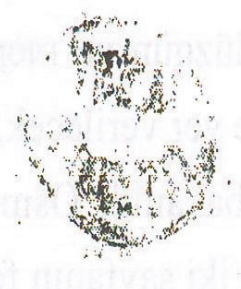


Tablo 2. Güvemli Bey Vakfínın Merkez Muhasebecileri tarafindan tutulan H. 1127 / M. 1715 yılı muhasebesinin sadeleştirilmiş çevirisi.

\begin{tabular}{|c|c|c|c|c|c|}
\hline \multicolumn{6}{|c|}{ Eski Zağra'da merhum Güvemli Bey Vakfinın Gelir ve Gider Muhasebesi } \\
\hline \multicolumn{6}{|c|}{$\begin{array}{l}\text { Vakıf kurucusu tarafindan konulan şart gereğince mütevelli olan oğlu Ali Bey sorumluluğunda, önceki } \\
\text { yılın Şubat ayından } 1127 \text { yılııın Mart ayı başına kadar tüm yılı kapsayan gelirler: } 26.640 \text { Akçe }\end{array}$} \\
\hline \multicolumn{6}{|c|}{ YIllık Gelirler } \\
\hline \multicolumn{3}{|c|}{$\begin{array}{c}\text { Kasabadaki dükkanların kira gelirleri. } \\
1127 \text { yılı Mart ayına kadar kiracısının ödediği } \\
\text { Adet: } 6 \\
\text { Aylık: } 120 \\
\text { Yılık: } 720 \text { Akçe }\end{array}$} & \multicolumn{3}{|c|}{$\begin{array}{l}\text { Vakfa ait tımarın, vakfin mütevellisi, katibi ve tahsil- } \\
\text { darı tarafindan tahsil edilen } \\
\text { yılık: } 1880 \text { Akce }\end{array}$} \\
\hline \multicolumn{6}{|c|}{$\begin{array}{l}\text { Geliri vakfa verilmiş tarımsal alanın öşür vergileri mütevelli, katip ve tahsilat görevlisi tarafindan } 1127 \\
\text { Mart öncesi tahsil edilen gelir }\end{array}$} \\
\hline & $\begin{array}{c}\text { Buğday } \\
\text { Keyl: } 200 \\
\text { Birim: } 50 \\
\text { Yıllık: } 10.000 \text { Akçe }\end{array}$ & & & $\begin{array}{l}\text { Mercimek } \\
\text { Keyl: } 468 \\
\text { Birim: } 30 \\
\text { k: } 14.040 \text { Aks }\end{array}$ & \\
\hline \multicolumn{6}{|c|}{ Toplam 26.640 Akçe } \\
\hline Önceki yılın Şub & at sonundan 1127 yı & $\begin{array}{r}\text { nın Mart ba } \\
\text { Günl } \\
\text { Yıllık: }\end{array}$ & $\begin{array}{l}\text { na kadar bir yıllık Du } \\
\text { : } 61 \text { Akçe } \\
.960 \text { Akçe }\end{array}$ & vakif & arı giderleri \\
\hline \multicolumn{6}{|c|}{ Çalışanların günlükleri } \\
\hline $\begin{array}{l}\text { Ali Bey } \\
\text { Mütevelli }\end{array}$ & $\begin{array}{l}\text { Ahmed halife } \\
\quad \text { katip }\end{array}$ & $\begin{array}{l}\text { Mehmed } \\
\text { halife } \\
\text { tahsildar }\end{array}$ & $\begin{array}{l}\text { Mustafa halife } \\
\text { şeyh }\end{array}$ & $\begin{array}{l}\text { Mustafa } \\
\text { mescid } \\
\text { imamı }\end{array}$ & $\begin{array}{l}\text { Ali mescid } \\
\text { müezzini }\end{array}$ \\
\hline Günlük 7 & Günlük 2 & Günlük 2 & Günlük 3 & Günlük 3 & Günlük 2 \\
\hline \multirow[t]{2}{*}{$\begin{array}{l}\text { Eczane } \\
\text { görevlisi }\end{array}$} & Mehmed ekmekçi & $\begin{array}{l}\text { Ahmed } \\
\text { aş̧̧ı }\end{array}$ & $\begin{array}{l}\text { Mehmed Güvemli } \\
\quad \text { Bey oğlu }\end{array}$ & $\begin{array}{l}\text { Hasan } \\
\text { mescid } \\
\text { müezzini }\end{array}$ & $\begin{array}{c}\text { Mustafa } \\
\text { halife mescid } \\
\text { hademesi }\end{array}$ \\
\hline & & & Günlük 3 & Günlük 2 & Günlük 2 \\
\hline $\begin{array}{l}\text { Mehmed } \\
\text { Edirne mescidi } \\
\text { imamı }\end{array}$ & $\begin{array}{l}\text { Ebubekir Edirne } \\
\text { mescidi müezzini }\end{array}$ & $\begin{array}{l}\text { Mehmed } \\
\text { duacl }\end{array}$ & $\begin{array}{l}\text { Halil yardıma } \\
\text { yönetici }\end{array}$ & & \\
\hline Günlük 7 & Günlük 4 & Günlük 5 & Günlük 5 & & \\
\hline \multicolumn{6}{|c|}{ Masraflar... 4.680} \\
\hline \multicolumn{2}{|c|}{$\begin{array}{l}\text { İmaret masrafi: Alışılagelen } \\
\text { masraflar }\end{array}$} & \multicolumn{2}{|c|}{$\begin{array}{l}\text { Mescidlere yağ kandili } \\
\qquad 2 \text { adet }\end{array}$} & \multicolumn{2}{|c|}{$\begin{array}{c}\text { Vakıf muhasebesi; Muhasebe- } \\
\text { ci ücreti ve muhasebe kalemi } \\
\text { masrafları } \\
300 \text { Akçe }\end{array}$} \\
\hline \multicolumn{6}{|c|}{ Aylık: 90 Akçe } \\
\hline \multicolumn{6}{|c|}{ YIllık: 1.080 Akçe } \\
\hline \multicolumn{6}{|c|}{ Çeşitli harcamalar } \\
\hline Mütevelli sorum & luluğunda yıllı & len gide & 300 Akçe & & \\
\hline
\end{tabular}


Belge 2 ile ilgili açıklamalar aşağıdadır:

- Bu defter kaydı, Osmanlı́nın genel muhasebe kültürünün vakıf muhasebesine yansımış şeklidir. Girişteki genel ifadeler, tarihlere açıklık getirilmesi ve tüm kayıt düzeni bir akıcılık göstermektedir.

- Her iki defter kaydı arasında farklar vardır. Merkezde tutulan defterin daha ayrıntlı bilgileri kapsadığı görülmektedir. Vakfin bulunduğu yerdeki muhasebesinden gelen bilgilerin, sadece defter kayıtlarından oluşmadığı, bir dosya halinde merkeze bütün bilgilerin gönderildiği ve bu bilgilerden yararlanılarak defterin yeniden düzenlendiği anlaşılmaktadır.

- Merkezdeki bilgili muhasebeciler, gelen defter kaydını ve gelen öteki bilgileri incelemişler ve Güvemli Bey Vakfinın H. 1127 / M. 1715 yılı Mart ayı başına kadar olan bir yıllık muhasebesini, önce gelirler ve sonra giderler olarak ayrıntılı, anlaşılır ve açık bir şekilde ortaya koymuşlardır.

- Bu kayıtlarda yıllık gelir ve gider tutarlarının eşit olduğu görülmektedir. İlk defter kaydındaki gider fazlası, ikinci defter kaydında yoktur. Çünkü merkezdeki muhasebeciler, taşradaki muhasebecilerden daha bilgilidir ve daha dikkatle bilgileri inceleyip, kayıtları yapmışlardır.

- Bütün bu kayıtlar, merkezî muhasebenin sadece vakıfların gelir ve giderlerini kontrolle yetinmediklerini, taşra muhasebecilerinin muhasebe bilgisi eksiklerini de tamamlamak durumunda kaldıklarını göstermektedir.

Belirtmek gerekir ki, vakıf muhasebesinin kontrolünü yapan ve mahallindeki kayıtların eksiklerini gidermeye çalışan bu muhasebecilerin asıl görevleri Osmanlı devlet muhasebesini yürütmektir. Vakıf muhasebesi, bu büyük örgütün içinde, yukarda belirtilen iki departmanında (Küçük evkaf muhasebesi kalemi, Haremeyn muhasebesi kalemi) yürütülmektedir. Bu iki departman, büyük Osmanlı muhasebesi örgütünün bir parçasıdır. Bu durumda sözü edilen örgütün yaptığı işlerden söz etmek uygun olacaktr.

\section{Vakıf Muhasebesinin İçinde Bulunduğu Devlet Muhasebe Sistemi}

\section{a) Devlet Muhasebe Sistemi içinde Vakıflara Sağlanan Ayrıcalıklı Hizmetler}

Imparatorluğun yıllık gelir ve gider hesapları bir defter sistemi içinde yürütülür. Bu defter sisteminin iki temel amacı vardır. Bunlardan birincisi yıllık kesin gelir ve gider hesabının düzenlenmesi ve devletin kasası olan hazinenin yönetimidir. İkinci temel amaç ise, muhasebenin birinci temel amacın gereği gibi yerine getirilebilmesi için kontrol fonksiyonunu yerine getirir. Bu iki temel amaca yönelik devlet muhasebesi sistemi içinde vakıfların muhasebesi ve bu muhasebenin amacı istisna teşkil eder. Bu istisnaları aşağıdaki şekilde sıralamak mümkündür.

Asıl görevleri olmadığı halde merkezî muhasebe örgütü vakıfların muhasebe düzeni ile de uğraşırlar. Hem de bütün kayıtları yeniden yapacak kadar çok uğraşırlar.

Merkezî muhasebe çalışanları bu hizmetleri karşılığında vakıfların gelirlerinden pay almazlar. Çünkü muhasebede çalışanların ücretleri, verdikleri berat (izin) belgeleri gibi hizmetlerden aldıkları paylardan karşılanır. Bu hizmetler, yukarıdaki örnekte görüldügü üzere, mahallinde tutulan defterlerin yeniden düzenlenmesine kadar uzanan meşakkatli bir iştir. Vakıf defterlerinde görülen muhasebeci (katip) ücreti, vakfin bulunduğu yerde muhasebesini yürütmeye çalışan muhasebeciye (katip) verilen ücrettir. Taşradaki bu muhasebeciler, bugün çeşitli kentlerde büroları olan, bağımsız çalışan muhasebeciler gibidir.

Devlet kimi vakıflardan hazinesine koymak üzere gelir sağlar, bu departmanlar bu gelirleri tespit eder ve devletin yıllık gelirlerine eklemek üzere tahsil eder. Ama yıllık gelirlerinden devletin hazinesine koymak üzere pay aldığı vakıflar azdır. Çoğu vakıf, devlete gelirinden pay vermez. Vakfin sosyal amaca dönük hizmet vermesi, gelirinden devlete pay vermesini önler. Devlet muhasebesi, bu sosyal amaç nedeni ile ayırım yapamadan bütün vakıflara hizmet verir. Bu, merkezî muhasebenin sosyal amaçlara yönelik hizmetlere bir katkısıdır. Kontrol amaçlı bir katkıdır. Yani vakfin gelir ve giderinin vakıf senedine ve genel vakıf kurallarına uygunluğunun tespitine dönüktür. 
Muhasebe bu hizmeti ile, kamu yararına geleneksel kontrol fonksiyonunu yerine getirirken, dolaylı olarak muhasebe mesleğinin kalitesinin yükselmesine de katkıda bulunmuş olur. Çünkü yeniden düzenlenmiş vakıf defterlerini gören vakfin mahallindeki muhasebeci, eksiklerini görecek ve mesleki bilgisini tamamlamaya çalışacaktır.

Burada son olarak belirtilmesi gereken husus, devlet muhasebesinde kullanılan merdiven yönteminin, vakıflardaki kullanımının tek istisnası olmasıdır. Çünkü merdiven yöntemi kâr hesaplamaya elverişli olmadığı için işletmelerde kullanılmamıştr.

\section{b) Osmanlı'da Devlet Muhasebe Sisteminin Ana Yapısı}

Vakıflara istisnai bir şekilde hizmet veren devlet muhasebe sistemi üzerinde az da olsa durmak gerekmektedir. Böylece vakıf muhasebesinin nasıl bir örgüt içinde yürütüldüğü ortaya konulabilecektir.

\section{b1. Yıllık Gelir-Gider Hesabının Düzenlenmesine ve Hazinenin Yönetimine Dönük Defter Sistemi}

Bu kümede yer alan defterler, iki ana gruba ayrılır. Illk grubu, günlük defter (ruznamçe), ikinci grubu ise, büyük defter hesabı niteliği taşıyan yardımcı defterler oluşturur (Güvemli ve Güvemli, 2015: 27). Büyük defter demek, her konu için açılan hesapları ayrı ayrı gösteren defter demektir. Bu hesaplar devlet muhasebesinde fazla hacimli olduğundan, her hesap için ayrı defter tutulması söz konusu olmuştur.

Osmanlı devlet muhasebesinde günlük defterin (ruznamçe) üç fonksiyonu vardır. Bu fonksiyonların ilki, günlük gelir ve giderlerin izlenmesine olanak sağlamasıdır. İkinci fonksiyonu merkezî hazinenin yönetimine yönelik kayıt düzenine sahip olmasıdır. Yani hazineye girişlerin ve hazineden çıkışların günlük defter kayıtlarına bağlı olarak yapılması söz konusudur. Bu merkezî hazinenin, başka bir deyişle devlet kasasının yönetimi demektir. Üçüncü fonksiyon ise, yardımcı defterler olarak adlandırılabilecek (büyük defter hesabı niteliğinde) ikinci grupta yer alan defterlerin kayıtlarının kontrollünü sağlamaktrr. Örneğin, bir cizye geliri geldiğinde, önce cizye departmanında o bölgenin cizye defterine kayıt yapılır. Bu defter, sözü edilen yardımcı defterlere bir örnektir. Yardımcı deftere yapılan bu kayıt, bilgi aktarma belgesine yazılır (tahvil), bu bilgi aktarma belgesi ve para günlük defterin bulunduğu yere gelir. Tahvil belgesindeki bilgiler günlük deftere geçirilir. Para hazineciye teslim edilir (sergi departmanı). Günlük deftere yapılan kayda ait tarih ve madde numarası da aynı tahvil belgesine işlenir. Sonra tahvil belgesi cizye bölümüne gönderilir ve orada hıfzedilir. Böylece, yardımcı defter ile hazine arasındaki bağı günlük defter kurmuş olur. Daha sonra bir sorun, bir anlaşmazlık çıkarsa, tahvil belgesinde yazılı olan her iki bölümün defterlerindeki kayıt tarih ve numaraları izlenerek soruna yanıt aranır. Osmanlı muhasebesinde genellikle gelirler için ayrı, giderler için ayrı günlük defter tutulduğunu da bu arada belirtmek gerekir. Gelir ve giderler için ayrı günlük defterin tutulması hazinenin yönetiminde kolaylık sağlar.

$\mathrm{Bu}$ bölümde ikinci grubu oluşturan defterler (yardımcı defterler, büyük defter hesabı niteliğinde olan defterler) ikiye ayrılır. Illk alt grubu oluşturan defterler, devletin gelirlerinin (cizye defterleri, mukataa defterleri, adet-i ağnam defterleri, harç-ı hassa defterleri gibi) kayıt edildiği defterlerdir. Íkinci alt grubu oluşturan defterler de devletin giderlerinin (süvari kalemi, yeniçeri kalemi, silahdar kalemi, masraf-ı şehriyari, büyük kale kalemi, küçük kale kalemi gibi) kayıt edildiği defterlerdir.

Bu noktada aşağıdaki dört hususun açıklanmasında yarar vardır:

- Yukarıda yardımcı defterler olarak adlandırılan gelir ve gider defterlerinin gelir tutarları ve gider tutarları, yılsonunda toplanarak türlerine göre sıralanır ve böylece devletin yıllık kesin gelir ve gider hesabı düzenlenmiş olur. Yıllık olarak düzenlenen bu hesap bütçe değildir. Bütçe demek tahmin demektir. Oysa bu hesap yardımcı defterlerin adları itibarı ile (cizye gelirleri, mukataa gelirleri, silahtar ücret giderleri, yeniçeri ücret giderleri gibi) gerçekleşen gelir ve giderleri gösterir.

- Osmanlı'da tahakkuk muhasebesi uygulanır. Yani yılbaşında vergi yükümlüsüne, ödeyece- 
ği vergi bildirilir. Ve yıl içinde taksitle tahsilat yapılır. Giderler için de aynı yol izlenir. Bu nedenle önceki yıla ait yıllık kesin hesabın sonraki yııın başlarında (Muharrem ayı gibi) sadrazamlığa teslim edilmesi gerekir. Bunun için özellikle XVII. yüzyılın ikinci yarısında önlem alındığı ve dokuz aylık fiili gerçekleşmelere üç aylık tahminlerin, sonra düzeltilmesi kaydı ile eklendiği görülmektedir.

- Devlet muhasebesinin başında başdefterdar vardır. Başdefterdara bağlı olarak da defterdarlar görev yaparlar. Departmanlar bu defterdarlara bağlıdır. Aşağıdan yukarı doğru muhasebede çalışanların unvanları şakirt (çırak), kalfa, halife, baş halife şeklinde sıralanır. Çocuk yaşta işe alınırlar ve iş başında eğitilirler.

- Osmanlı devlet muhasebesi örgüt yapısı, yukarda belirtildiği üzere, XVII. yüzyılın ikinci yarısının başlarında düzenlenmiştir. 1665-66 Yıllarında yapılan bu değişikliğe göre (Güvemli, 2000: 374-398) daha önce bölgeler itibarı ile tutulan defter sistemi, bu tarihten sonra konulara göre kümelenmiştir. Yani daha önce mukataa departmanları, cizye departmanları, imparatorluğun bölgelerine göre ayrılan departmanlarda tutulurken, bu tarihten sonra bütün mukataa departmanlarının, bütün cizye departmanlarının birleştirilmesine ve tek departman haline getirilmesine çalışılmıştr. Öteki gelir ve gider departmanları için de aynı yol izlenmiştir. Bu yeniden yapılanma sonrası iki yarar sağlanmıştır. Bilgilerin toplanması kolaylaşmış ve bir de iş bazında intisaslaşma olanağı artmıştır. Daha önce defterdarlara bölgeler bağlı iken, bu değişiklikten sonra konularına göre kümelenen departmanlar bağı hale gelmiştir. Bu nedenle devlet muhasebesi üzerinde çalışanların bilgi toplamada bu duruma (1666 öncesi ve sonrasına) dikkat etmeleri gerekmektedir.

\section{b2. Kontrol Amaçlı Rapor Defterleri}

Bu gruptaki defterler, ilk grubu oluşturan muhasebe sisteminin düzgün yürümesine ve devlet gelir ve giderlerinin kontrolüne yönelik bir nitelik taşır. Belirli bir konuda düzenlenmiş kontrol ve denetim raporları şeklindedirler.

Osmanlı devlet muhasebesinin özelliği, defter deyiminin, günlük defter ve yardımcı defterler yanında, muhasebe kontrol raporları için de kullanılmasıdır. Oysa muhasebede defter düzeni, zamana bağlı sürekliliği ifade eder. Ama kontrol raporları ihtiyaç duyulduğunda hazırlanır. Osmanlı muhasebe sisteminde bu raporların yazııdığı, yer aldığı belgelere de defter denilir. Bu nedenle, bu bölümün açıklanmasında da defter sözcüğü kullanılmıştr.

Bu gruptaki defterleri üç alt grupta toplamak olanağı vardır. Illk alt grubu oluşturan defterler, devlet gelirlerinin kontrolü ile ilgili raporları içerir. Örneğin belirli bir mukataa ile ilgili işler, sözleşmesine uygun olarak yürümüyorsa, nedenini araştırmak ve düzene sokmak için bir rapor düzenlenir (Güvemli ve Şensoy, 2013: 1139). Ya da bir bölgeden alınan cizye gelirlerinde düşme olursa bu raporlar düzenlenir. Bunlar Osmanlı devlet arşivlerinde mukataa ve cizye defterleri arasında yer alırlar, ama ilk bölümdeki defterlerden farklı fonksiyonları vardır. Bunlar müfettiş raporları niteliğindedir.

ikinci alt grubu oluşturan defterler ise, devlet giderlerinin kontrolüne yönelik defterlerdir. Örneğin, Galata Tersanesi'nin bir yıllık gelir ve giderlerinin hesaplanmasına yönelik raporun ayrıntisı, tersaneye yıllık olarak gönderilen para ve malzemenin kullanım yerlerinin saptanmasına yönelik amaç taşıyabilir. Bu tür raporlar, Matbah-ı âmire, Istabl-ı âmire, Darphâne için de hazırlanabilir. Genellikle amaçları, hem kontrol ve hem de o yerin harcamalarının ve varsa gelirlerinin izlenmesi ihtiyacının karşılanmasıdır.

Üçüncü alt grubu oluşturan raporlar, gelirler ya da harcamalarda yolsuzluk ihbarı üzerine ve vadesi geçmiş devlet alacağının tahsil olanağının araşt-rılması gibi konulara yönelik olarak hazırlanmışlardır. Bu tür raporlar daha çok bâki kulları (Emecen, 1994: 34) tarafindan düzenlenmiştir. 
Kontrol ve denetim amaçı ı raporları içeren muhasebe defterleri çok sayıda olduğu için burada yer verilmiştir.

Bu araştırma iki amaç için hazırlanmıştr. Illk amaç, Osmanlı vakıflarının uzun ömürlü olmalarının iki nedeninden birisinin vakıf muhasebe düzeni olduğunu ortaya koymaktır (öteki neden hukuki düzendir). Çünkü vakıf demek para hareketi demektir ve yolsuzluk genellikle, vakıf da olsa, para hareketlerinde ortaya çıkar. Bunun da çaresi sağlam bir muhasebe kontrolüne sahip olmaktr.
Bu araştırmanın hazırlanmasının ikinci nedeni, Osmanlı muhasebesinden sağlanan bilgileri kullananlara yardımcı olmaktr. Bilindiği gibi, maliye tarihi, iktisat tarihi gibi tarihî konuların bilgileri çoğu zaman Osmanlı devlet muhasebesinden derlenmektedir. Bu araştrmaları yapanlar, genellikle asgari de olsa, muhasebe tekniği bilgisine sahip olmayabilirler. Bu yazı ile onlara birazcık da olsa, yardımcı olmak ve aldıkları bilginin muhasebe sisteminin neresine ait olduğunu bilmelerine yardım etmektir. Birazcık da olsa denilmesinin nedeni, bu araştrrmada sadece ana çizgilere değinilmiş olmasıdır. 


\section{Kaynaklar}

\section{1- Arşiv Kaynakları}

Başbakanlık Osmanlı Arşivi, EV HMH.d. 02051.

Topkapı Sarayı Arşivi, 3208/1.

\section{2- Araştirma ve Inceleme Eserler}

Akgündüz, Ahmet (1992). Osmanlı Kanunnameleri. Osmanlı Araştırmaları Vakfi Yayınları. (4.Kitap). İstanbul.

Barkan, Ömer Lütfi (1962-63). “Osmanlı Imparatorluğu’nda İmaret Sitelerinin Kuruluş ve İşleyişi Tarzına Dair Araştırmalar". iktisat Fakültesi Mecmuası. (23). İstanbul. s. 1-2.

D' Ohsson, I.M. (1787-1820). Tableau General de L'Empire Othoman. (3. Kitap). s. 342-379.

Güvemli, Oktay ve Fatma Şensoy (2013). "The Accounting Records at Mukataas and the Example of Bursa Mukataa from 16th Century". 3rd Balkans and Middle East Countries Conference on Auditing and Accounting History (3BMAC). İstanbul. s. 1139.

Güvemli, Oktay (2000). Türk Devletleri Muhasebe Tarihi, Osmanlı Imparatorluğu, Tanzimat'a Kadar. (2). 2. Baskı. ìstanbul. s. 374- 398.

Güvemli, Oktay ve Cengiz Toraman (2013). Risale-i Felekiyye-Kitab-us Siyakat. İstanbul. s.15.

Güvemli, Oktay ve Batuhan Güvemli (2007). "The Birth and Development of an Accounting Method in the Middle East". The Fifth Accounting History International Conference. Banf - Kanada. s. 9-11.

Güvemli, Oktay ve Güvemli, B. (2015). “Osmanlı Devlet Muhasebesinde Kayıt Düzeni ve Defter Sistemi”. Muhasebe ve Finans Tarihi Araştrrmaları Dergisi. (9). s.27.

Güvemli, Oktay, Cengiz Toraman ve Batuhan Güvemli (2014). Osmanlı Imparaorluğu'nda Devlet Muhasebesi" Anadolu Kayıt Kültürü. Kamu Gözetimi Muhasebe ve Denetim Standartları Kurumu Yayınları. Ankara. s. 371-400.

Şensoy, Fatma (2016). "Osmanlı İmparatorluğu'nda Vakıfların Ekonomik Boyutları". Muhasebe ve Finans Tarihi Araştirmaları Dergisi. (10). s. 43.

Emecen, Feridun (1994). "Başbâki Kulu". Türkiye Diyanet Vakfi islam Ansiklopedisi. (3). s. 34. 
Ek 1: 1670 (H.1081) Yılında Bab-ı Ali'de mevcut kalemlerin durumu (Topkapı Sarayı Arşivi, 3208/1: 1-2)
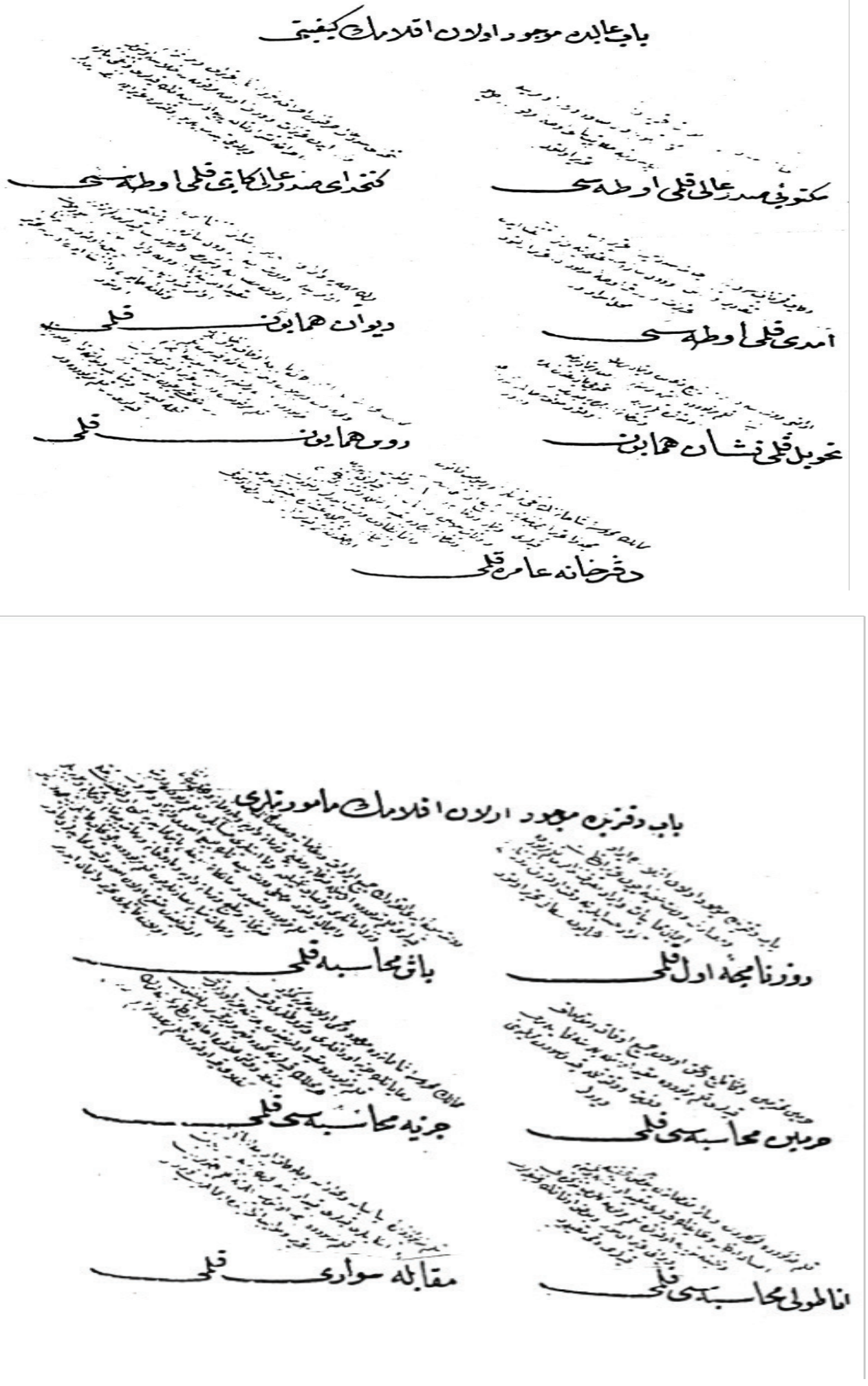

Vakıflar Dergisi 46- Aralık 2016 